\title{
ISOLATION, PARTIAL PURIFICATION OF PROTEINS PRODUCED BY LACTOBACILLUS BIFERMENTANS AND ITS ANTIBACTERIAL PROPERTIES
}

\author{
J.LAVANYA ${ }^{1}$, S.SUBHASHINI ${ }^{2}$ \\ ${ }^{1,2}$ Assistant Professor, ${ }^{2}$ Department of Biotechnology, School of Bioengineering, SRM University, \\ lavanya.j@ktr.srmuniv.ac.in.
}

\begin{abstract}
The Antibacterial properties of many Lactic Acid Bacteria were exhaustively studied by many researchers, but little information is known about Lactobacillus bifermentans. This study aims to comprehend the effect of Lactobacillus bifermentans on various Gram Positive and Gram Negative bacteria like Escherichia coli, Bacillus subtilis and Staphylococcus aureus. Testing of antibacterial activity of crude as well as partially purified bacterial sample by Size Exclusion Column Chromatography was performed using Disc Diffusion method, the results of which were comprehended by the measurement of inhibition zones observed. Isolated protein showed antibacterial activity against Bacillus subtilis and Staphylococcus aureus and no effect was observed on Escherichia coli. The inhibition zone diameters obtained were between $8 \mathrm{~mm}$ and $12 \mathrm{~mm}$.
\end{abstract}

Keywords: Lactobacillus bifermentans, Bacteriocin, Size Exclusion Chromatography, Disc Diffusion method, Antibacterial activity, Escherichia coli, Bacillus subtilis, Staphylococcus aureus.

\section{INTRODUCTION}

The lactic acid bacteria (LAB) comprise a clad of Grampositive, low GC content, acid-tolerant(able to grow at $\mathrm{pH} 4.4$ ) generally non-sporulating and non-respiring rod or cocci. Lactobacillus, also called Doderlein's bacillus, is a genus of Genus of Gram-positive facultative anaerobic or microaerophilic rod shaped bacteria. (21). They are catalase lacking organisms occur in naturally fermented food and drink $(23,16)$.

They are a major part of the lactic acid bacteria group, named as such because most of its members convert lactose and other sugars to lactic acid. In humans they are present in the vagina (9) and the gastrointestinal tract, where they make up a small portion of the gut flora (19). They are usually benign, except in the mouth where they have been associated with cavities and tooth decay (dental caries). Many species are prominent in decaying plant material. The production of lactic acid makes its environment acidic,which inhibits the growth of some harmful bacteria. Several members of the genus have had their genome sequence (20).

Lactobacilli, produce special antimicrobial compounds such as bacteriocins which are highly specific antibacterial proteins (2)prevents food spoilage and provides additional protection against Bacillus, ,S.aureus, Clostridial spores in canned foods. Many mechanisms have been postulated by which Lactobacilli could produce antimicrobial activity. In addition to their competitive inhibition of the epithelial and mucosal adherence of pathogens and inhibition of epithelial invasion by pathogens, Lactobacilli and Bifidobacteria show antimicrobial activity by producing antimicrobial substances and/or stimulating mucosal immunity.(26)

\subsection{LACTOBACILLUS BIFERMENTANS:}

Bifermentans means "doubly fermenting". A subgroup called L.coryneformis comprised of L.bifermentans and L.rennini. L.bifermentans is found to causing small cracks by gas formation in Edam and Gouda cheeses,has been isolated and described by Pette and Van Beynum(1943).

The biological origin of Lactobacillus bifermentans was from spoiled Blown Dutch cheeses (ie) Edam and Gouda cheese. It is an obligate aerobic bacterium. It has the exotic ability to carry out homolactic fermentation at high glucose concentration and also the ability to ferment lactate at $\mathrm{pH}>4.0$ to acetic acid, ethanol, traces of propionic acid, $\mathrm{Co} 2 \& \mathrm{H} 2$.

Cells are non-motile, irregular rods with rounded or often tapered ends $(0.5-1.0$ or $1.5-2.0 \mu \mathrm{m})$ occurring singly, in pairs, or irregular short chains, often forming clumps. It belongs to biohazard group I. The G $+\mathrm{C}$ content $(\mathrm{mol} \%)$ is 45 and the lactic acid isomer is DL. The carbohydrates fermented by more than $90 \%$ of the strains of L.bifermentans are Mannitol, Sorbitol \& Ribose. 
L.bifermentans was used to produce the intracellular enzymes L-arabinose isomerises and D-xylose isomerise. The medium used to grow L.bifermentans is MRS medium at $30^{\circ} \mathrm{C}$ at $\mathrm{pH}$ 6.2-6.6.

The strain used for our study is MA: RS. It is thus far the only species known to ferment lactic acid (anoxic degradation of lactic acid to acetic acid) without requiring an external electron acceptor and produce $\mathrm{H} 2$ gas to get rid of its excess of reducing equivalents.

\subsection{BACTERIOCINS:}

Bacteriocins are proteins which show bactericidal activity towards closely related species(27). There are 2 main reasons for studying bacteriocins in lactobacilli. Firstly, bacteriocin producing starter cultures may result in a more reliable fermentation process preventing growth of spoilage bacteria. Secondly, the genetic determinants for bacteriocin production and resistance to bacteriocins have great potential as genetic markers in rDNA technology for application in the future production of food additives or supplements from microorganisms. (3)

Plasmid encoded bacteriocins are commonly observed among both Gram - negative $(12,4) \&$ Gram-positive $(28,24,5,15)$. Bacteriocin produced by strains of Lactobacillus has been reported by $(7,30,1,22,6,14,10,31,25)$

\section{EXPERIMENTAL PROCEDURES:}

\subsection{BACTERIAL STRAINS AND MEDIA:}

Lactobacillus bifermentans MA:R5 strain of MTCC No.3818 was obtained from Microbial Type Culture Collection and Gene Bank, Institute of Microbial Technology, Chandigarh. The medium used to culture Lactobacillus bifermentans is MRS medium as it is growth specific and the optimum temperature for growth is $300 \mathrm{c}$. The indicator strains used to check antibacterial property of L.bifermentans were Escherichia coli, Bacillus subtilis and Staphylococcus aureus.

\subsection{ISOLATION OF ANTIMICROBIAL ACTIVE PROTEIN FROM MRS BROTH CULTURE:}

Lactobacillus bifermentans MA: R5 MTCC 3818 was grown on MRS medium for $48 \mathrm{hrs}$ at $300 \mathrm{c}$. Colonies were transferred into $20 \mathrm{ml}$ of MRS broth and incubated (aerobic conditions) at $300 \mathrm{c}$ for $48 \mathrm{hrs}$. This culture was used to inoculate 2 litres of MRS broth. The bacterial cells were harvested by centrifugation at $10,000 \mathrm{xg}$ for 15 minutes at $40 \mathrm{c}$. The supernatant containing the extracellular protein was collected and used further for checking the antibacterial effect on the indicator strains.

\subsection{ESTIMATION OF PROTEIN}

CONCENTRATION BY LOWRY'S METHOD:

Five test tubes marked as A, B, C, D, E of 0.2, 0.4, 0.6, 0.8 and $1.0 \mathrm{ml}$ of BSA working standard was taken and made up to $1.0 \mathrm{ml}$ using distilled water. A test tube with $1.0 \mathrm{ml}$ distilled water serve as a blank and marked as F. $1.0 \mathrm{ml}$ of centrifuged bacterial supernatant was taken in another test tube G. $4.5 \mathrm{ml}$ of Reagent I $(48 \mathrm{ml}$ of $2 \%$ sodium carbonate in $0.1 \mathrm{~N} \mathrm{NaOH}$, $1 \mathrm{ml}$ of $1 \% \mathrm{NaK}$ Tartarate in $\mathrm{H} 2 \mathrm{O}, 1 \mathrm{ml}$ of copper sulphate penta hydrate in $\mathrm{H} 2 \mathrm{O}$ ) and incubate for $10 \mathrm{~min}$. After incubation $0.5 \mathrm{ml}$ of Reagent II (1 part Folin Phenol [2N]: 1 part water) was added to all the test tubes and incubated for 30 min. After 30min incubation absorbance was taken at $660 \mathrm{~nm}$ and the standard graph was plotted. From the standard graph, the concentration of protein in the bacterial sample was estimated.

\section{TESTING THE ANTIBACTERIAL EFFECT OF}

\section{THE CRUDE BACTERIAL SAMPLE BY DISC DIFFUSION METHOD:}

8 test tubes were taken and marked as A, B, C, D, E, F, G, H. Test tube A was filled with $10 \mathrm{ml}$ of E.coli liquid culture and all the other 7 test tubes were filled with $9 \mathrm{ml}$ of distilled water. $1 \mathrm{ml}$ of E.coli culture was taken from test tube $\mathrm{A}$ and transferred to test tube $\mathrm{B}$. The test tube $\mathrm{B}$ was diluted by a factor of $10^{\wedge}-1$. Again $1 \mathrm{ml}$ of solution was taken from test tube $\mathrm{B}$ and transferred to test tube $\mathrm{C}$. Test tube $\mathrm{C}$ was diluted by a factor of $10^{\wedge}-2$. Similarly $1 \mathrm{ml}$ of solution was transferred to next test tube and diluted till I obtained a dilution factor of $10^{\wedge}-7$. Similar procedure was repeated for other two indicator strains i.e. Bacillus subtilis and Staphylococcus aureus. Nutrient Agar medium was prepared and autoclaved. Three autoclaved Petri plates with Nutrient Agar medium were taken. The 1st Petri plate with nutrient agar medium was swabbed evenly with $10^{\wedge}-7$ fraction diluted Escherichia coli culture, the 2nd one with $10^{\wedge}-7$ fraction diluted Bacillus subtilis and the $3 \mathrm{rd}$ one with $10^{\wedge}-7$ fraction diluted Staphylococcus aureus culture using sterilized L-Rod. Autoclaved what man filter paper discs of $5 \mathrm{~mm}$ were taken and aliquots of 50, 75 and $100 \mu 1$ (3 of each) of crude bacterial sample were applied onto the discs and placed on each Petri plate that were previously inoculated with the indicator strains. The what man filter paper disc absorbed with $50 \mu 1$ of autoclaved distilled water was placed on 3 Petri plates and was used as a negative control. Zone of Inhibition were observed and measured after $24 \mathrm{hrs}$ incubation at 370c. 


\section{PURIFICATION OF CRUDE BACTERIAL} SAMPLE BY SIZE EXCLUSION COLUMN (SEC) CHROMATOGRAPHY:

The matrix (stationary phase) was prepared by soaking 15 grams of Sephadex G50 powder in 0.05M TRIS-HCl buffer of $\mathrm{pH}-7$ with $0.1 \mathrm{~N} \mathrm{NaCl}$ for overnight. The bottom of the column was plugged with Glass wool and the stop cock was closed. The gel was poured into the column by avoiding air bubbles and was packed $50 \mathrm{~cm}$ high. To the other end of the opening of column, separating funnel was attached with a rubber tube. $500 \mathrm{ml}$ of wash buffer composed of $50 \mathrm{mM}$ Tris buffer and $125 \mathrm{mM} \mathrm{NaCl}$ was prepared and autoclaved. The separating funnel was filled with the elution buffer. The column was washed thrice with the 3 column volumes of elution buffer. Using syringe, $1 \mathrm{ml}$ of Blue Dextran was added at the top of the column and the stop cock was opened so that the dye Blue Dextran moves through the column. The stop cock of the separating funnel was also opened and the flow rate was set at $1.5 \mathrm{ml} / 3 \mathrm{~min}$. At a flow rate of $1.5 \mathrm{ml} / 3 \mathrm{~min}$, the volume eluted from the column was collected in a graduated cylinder and the volume at which the dye starts to elute from the column was noted. After all the Blue Dextran is past, again the volume was recorded. After the standardization of column with Blue Dextran, the column was again washed thrice with the column volume of buffer. After washing, the bacterial sample was filtered using $0.2 \mu \mathrm{m}$ filter and $1 \mathrm{ml}$ of sample was applied at the top of the column. The flow rate was set at $1.5 \mathrm{ml} / 3.30 \mathrm{~min}$ and 67 fractions were collected in a $1.5 \mathrm{ml}$ eppendorf tubes. The stop cock was closed after collecting 67 fractions and the absorbance at $280 \mathrm{~nm}$ was recorded for all the 67 fractions.

\section{TESTING THE ANTIBACTERIAL EFFECT OF} THE COLUMN PURIFIED SAMPLE BY DISC

\section{DIFFUSION METHOD:}

3 autoclaved petri plates with nutrient agar medium were taken and inoculated with $10^{\wedge}-7$ fraction diluted E.coli, B.subtilis and S.aureus culture. After recording the absorbance at $280 \mathrm{~nm}$ for the collected fractions, the fraction which has obtained the highest absorbance was selected to check the antibacterial effect on indicator strains because it has the highest concentration of protein in it. The discs were saturated with 50, 75 and $100 \mu 1$ of the selected fraction and were placed on the plates. The autoclaved distilled was used as a negative control. The petri plates were incubated at 370c for $24 \mathrm{hrs}$ and the zone of inhibition was measured and recorded after $24 \mathrm{hrs}$ incubation.

\section{RESULTS:}

\subsection{ESTIMATION OF PROTEIN}

\section{CONCENTRATION BY LOWRY'S METHOD:}

On performing Lowry's method, the following O.D values at $660 \mathrm{~nm}$ were observed.

\begin{tabular}{|c|c|c|}
\hline S.NO & $\begin{array}{l}\text { VOLUME } \\
\text { OF BSA } \\
\qquad(\mathrm{ml})\end{array}$ & $\begin{array}{c}\text { O.D at } \\
660 \mathrm{~nm}\end{array}$ \\
\hline 1 & 0.2 & 0.368 \\
\hline 2 & 0.4 & 0.916 \\
\hline 3 & 0.6 & 1.148 \\
\hline 4 & 0.8 & 1.474 \\
\hline 5 & 1.0 & 1.257 \\
\hline Blank & - & 0 \\
\hline $\begin{array}{l}\text { Bacterial } \\
\text { Sample/ Test } \\
\qquad(1 \mathrm{ml})\end{array}$ & - & 2.446 \\
\hline
\end{tabular}

With the above O.D values, the standard graph was drawn between concentration of BSA $(\mathrm{mg} / \mathrm{ml})$ and the O.D at $660 \mathrm{~nm}$ on $\mathrm{X}$-axis and $\mathrm{Y}$-axis respectively. The slope obtained from the standard graph was 1.63 . 


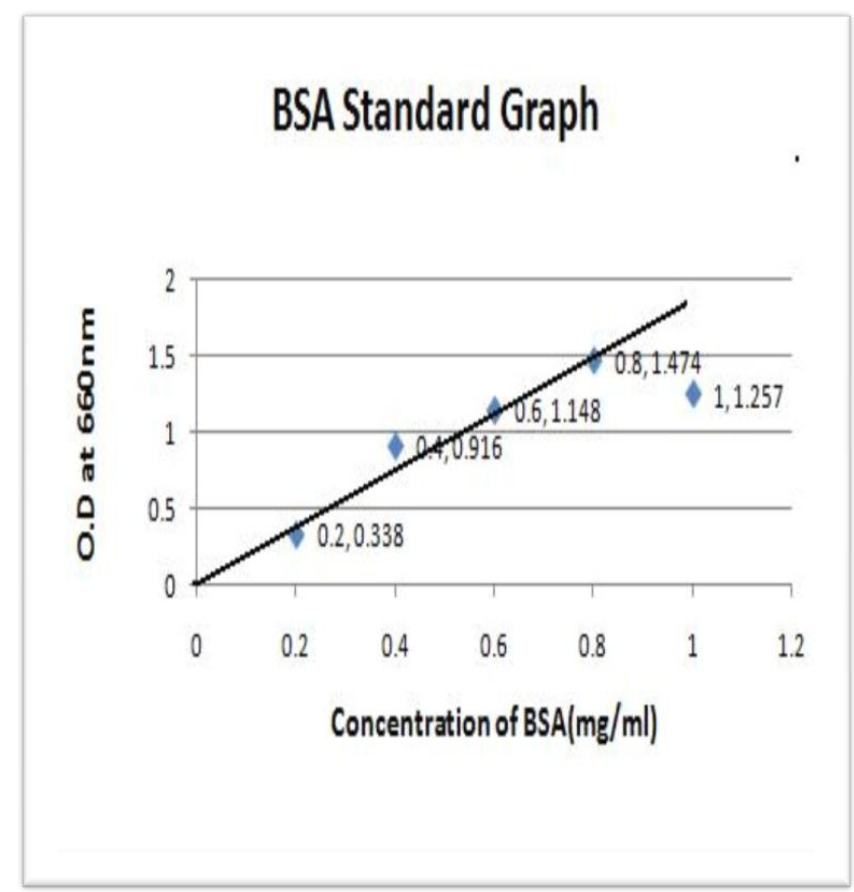

The Graph was drawn between the volume of sample $(\mathrm{ml})$ and the concentration of protein $(\mathrm{mg} / \mathrm{ml})$ present in the respective volume of sample on $\mathrm{X}$-axis and $\mathrm{Y}$-axis respectively.

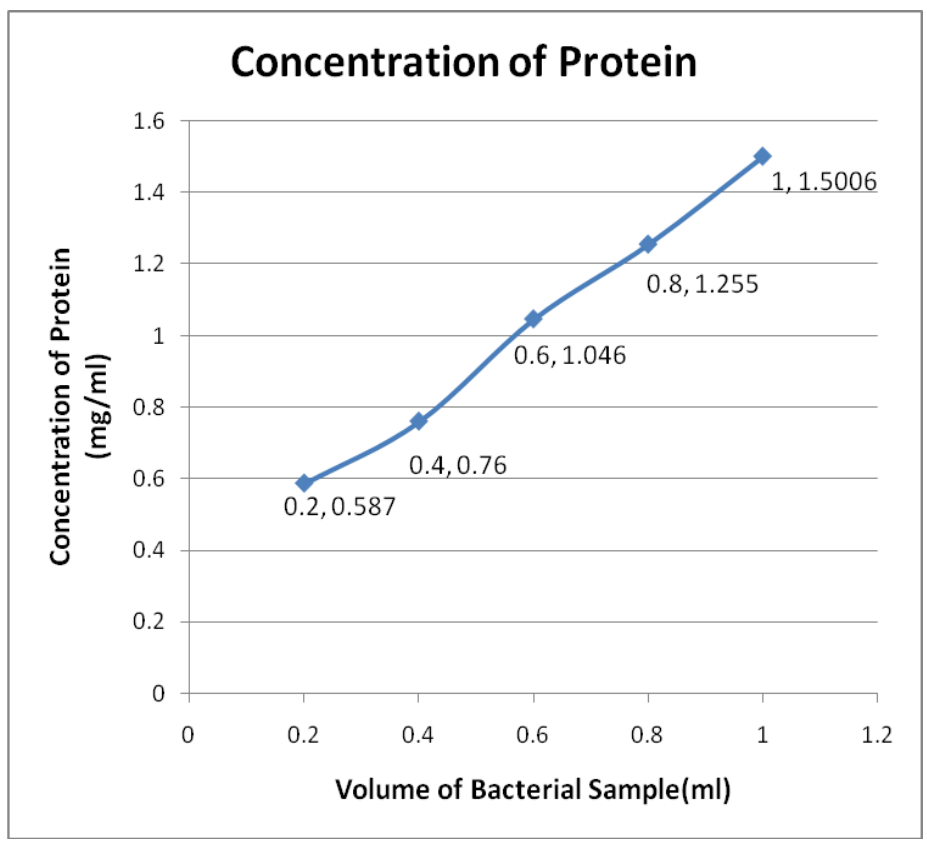

On plotting the graph, it was observed that the concentration of protein in the sample increased as the volume of sample increased.

The Concentration of protein present in the bacterial sample was $1.5006 \mathrm{mg} / \mathrm{ml}$

\section{TESTING OF ANTIBACTERIAL EFFECTS OF CRUDE PROTEIN}

On testing the antibacterial effect of centrifuged L.bifernmentans MA:R5 MTCC 3818 supernatant, the Zone of Inhibition was observed after incubation for $24 \mathrm{hrs}$ at $370 \mathrm{c}$ for Bacillus subtilis and Staphylococcus aureus. The Zone of Inhibition was not seen for Escherichia coli.

50,75 and $100 \mu 1$ are the volumes of bacteriocin containing sample saturated on whatman filter paper discs. The negative control used here is $50 \mu \mathrm{l}$ of autoclaved distilled water.

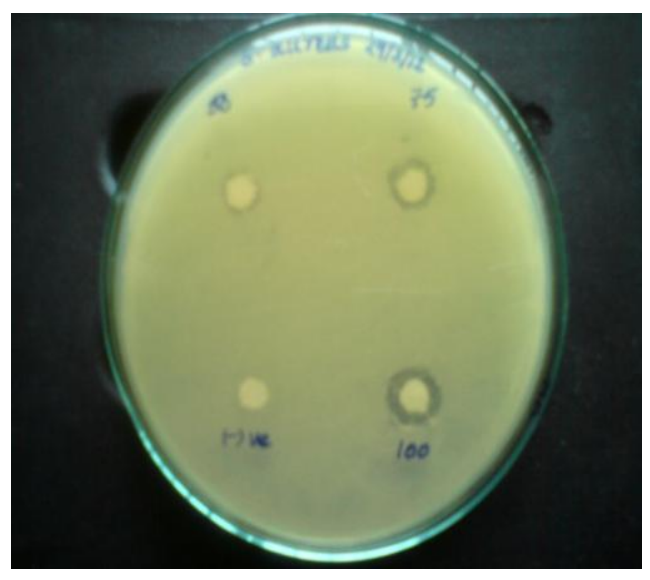

\begin{tabular}{|c|c|}
\hline $\begin{array}{ll}\text { VOLUME } & \text { OF } \\
\text { BACTERIOCIN } & \\
\text { CONATAINING } & \text { SAMPLE } \\
(\mu \mathrm{l}) & \\
\end{array}$ & $\begin{array}{c}\text { DIAMETER OF ZONE } \\
\text { OF INHIBITION OF } \\
\text { Staphylococcus aureus } \\
\text { (mm) }\end{array}$ \\
\hline 50 & 8.0 \\
\hline 75 & 9.0 \\
\hline 100 & 11.0 \\
\hline
\end{tabular}

ZONE OF INHIBITION FORMED ON Staphylococcus aureus by

L.bifermentans 


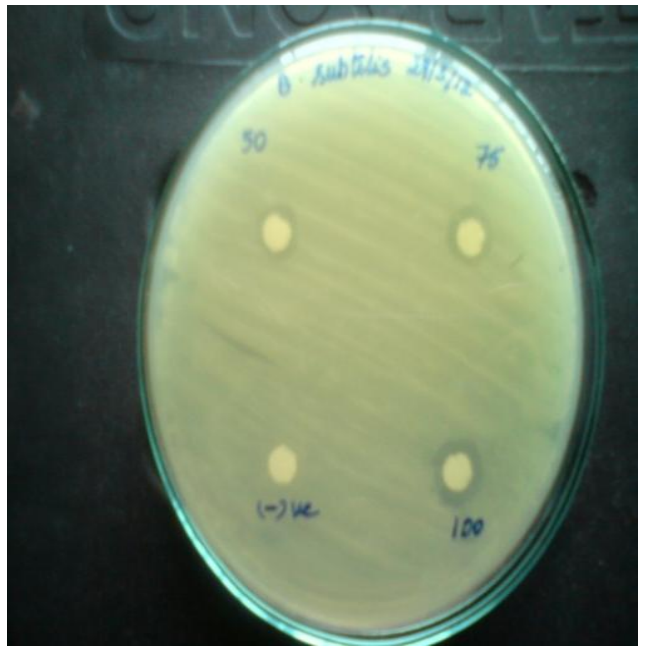

ZONE OF INHIBITION FORMED ON Bacillus subtilis by L.bifermentans

\begin{tabular}{|c|c|}
\hline $\begin{array}{l}\text { VOLUME OF } \\
\text { BACTERIOCIN } \\
\text { CONATAINING } \\
\text { SAMPLE }(\boldsymbol{\mu l})\end{array}$ & $\begin{array}{l}\text { DIAMETER OF ZONE } \\
\text { OF INHIBITION OF } \\
\text { Bacillus subtilis }\end{array}$ \\
\hline 50 & 9.0 \\
\hline 75 & 10.0 \\
\hline & \\
\hline & 11.0 \\
\hline
\end{tabular}

\section{PARTIAL PURIFICATION BY SIZE EXCLUSION}

\section{COLUMN (SEC) CHROMATOGRAPHY:}

The Void Volume obtained for Blue Dextran was $23 \mathrm{ml}$. On running the column at a flow rate of $1.5 \mathrm{ml} / 3.30 \mathrm{~min}$ loaded with $1 \mathrm{ml}$ of crude bacterial sample, 67 fractions were collected among which highest amount of protein was present in 35 th fraction collected after $54 \mathrm{ml}$ was eluted.

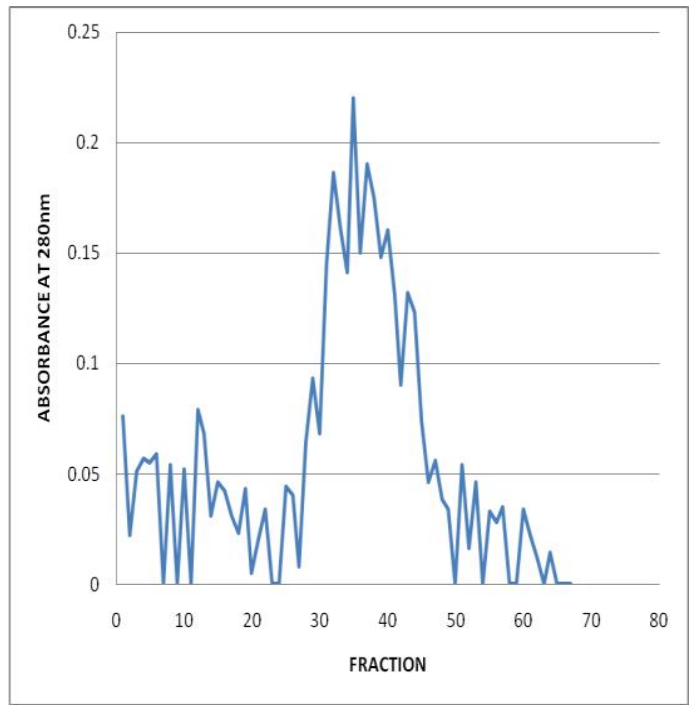

SIZE EXCLUSION COLUMN CHROMATOGRAM

TESTING OF ANTIBACTERIAL EFFECT OF SIZE EXCLUSION COLUMN (SEC)

\section{CHROMATOGRAPHY PURIFIED BACTERIAL}

\section{SAMPLE:}

The fraction No.34 and 35 which has an absorbance of 0.19 and 0.22 obtained on performing Size exclusion column chromatography were tested for antibacterial activity against Bacillus subtilis and Staphylococcus aureus. The Zone of Inhibition was observed after incubation for $24 \mathrm{hrs}$ at $370 \mathrm{c}$.

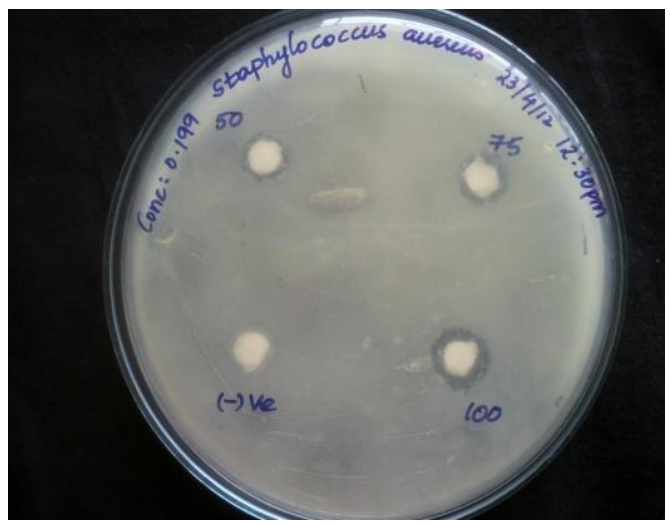

ZONE OF INHIBITION FORMED ON Staphylococcus auereus WHEN TESTED

WITH FRACTION NO.34 WITH ABSORBANCE OF 0.199 


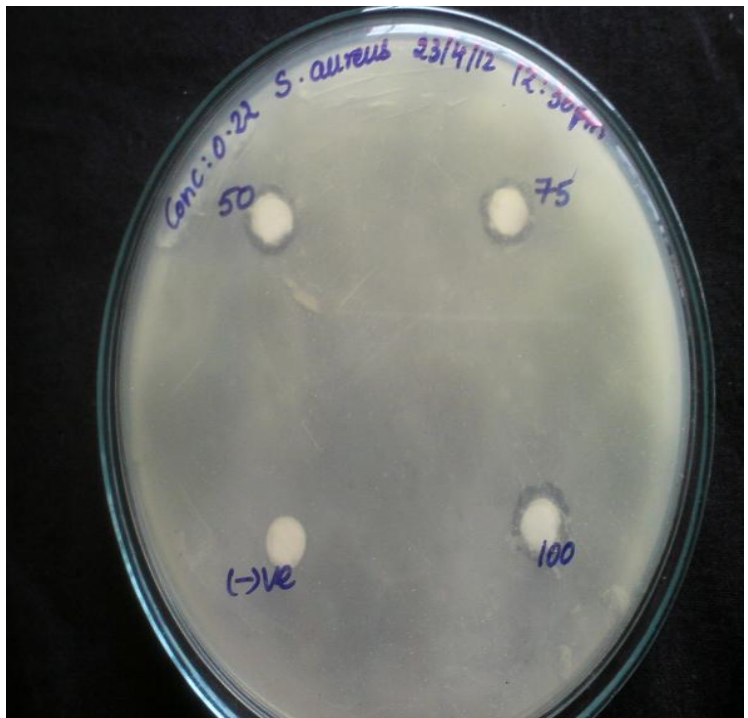

\section{ZONE OF INHIBITION FORMED ON Staphylococcus auereus WHEN TESTED}

\section{WITH FRACTION NO.35 WITH ABSORBANCE OF 0.22}

50,75 and $100 \mu l$ are the volumes of bacteriocin containing purified sample saturated on whatman filter paper discs. The negative control used here is $50 \mu \mathrm{l}$ of autoclaved distilled water. No Zone of Inhibition was observed for Negative control.

\begin{tabular}{|c|c|c|}
\hline $\begin{array}{l}\text { VOLUME } \\
\text { BACTERIOCIN } \\
\text { CONTAINING } \\
\text { SAMPLE }\end{array}$ & $\begin{array}{l}\text { OF } \\
\text { PURIFIED } \\
(\mu 1)\end{array}$ & $\begin{array}{ll}\text { DIAMETER } & \text { OF } \\
\text { ZONE OF } & \\
\text { INHIBITION } & \\
(\mathrm{mm}) & \end{array}$ \\
\hline & 50 & 9.0 \\
\hline & 75 & 10.0 \\
\hline & 100 & 11.0 \\
\hline
\end{tabular}

INDICATOR STRAIN: Staphylococcus aureus

FRACTION NO. $: 34$

ABSORBANCE $: 0.19$
INDICATOR STRAIN : Staphylococcus aureus

FRACTION NO. $\quad: 35$

ABSORBANCE $: 0.22$

\begin{tabular}{|c|c|}
\hline $\begin{array}{l}\text { VOLUME OF } \\
\text { BACTERIOCIN } \\
\text { CONTAINING } \\
\text { PURIFIED } \\
\text { SAMPLE }(\mu \mathrm{l})\end{array}$ & $\begin{array}{c}\text { DIAMETER OF } \\
\text { ZONE OF }\end{array}$ \\
\hline 50 & 8.0 \\
\hline 75 & 8.0 \\
\hline 100 & 9.0 \\
\hline
\end{tabular}
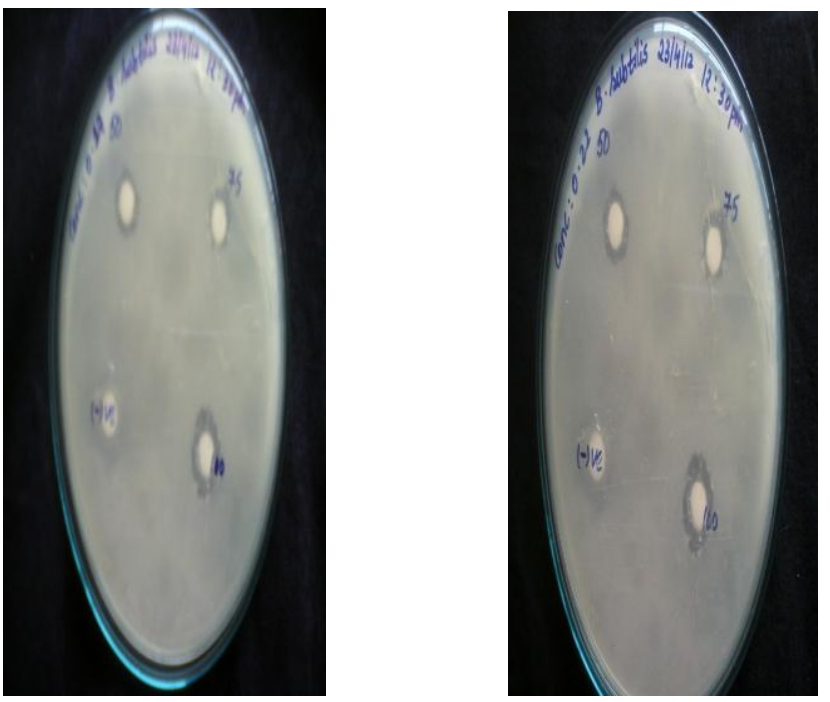

ZONE OF INHIBITION FORMED ON Bacillus subtilis WHEN TESTED

\section{WITH FRACTION NO.34 WITH ABSORBANCE OF 0.199}

INDICATOR STRAIN : bacillus subtilis

FRACTION NO. $\quad: 34$

ABSORBANCE $\quad: 0.199$ 


\begin{tabular}{|c|c|}
\hline $\begin{array}{c}\text { VOLUME OF } \\
\text { BACTERIOCIN } \\
\text { CONTAINING } \\
\text { PURIFIED SAMPLE }(\mu \mathrm{l})\end{array}$ & $\begin{array}{c}\text { DIAMETER OF ZONE } \\
\text { OF }\end{array}$ \\
& INHIBITION $(\mathrm{mm})$ \\
\hline 50 & 10.0 \\
\hline 75 & 10.0 \\
\hline & \\
\hline 100 & 12.0 \\
\hline
\end{tabular}

INDICATOR STRAIN : bacillus subtilis

$\begin{array}{ll}\text { FRACTION NO. } & : 35 \\ \text { ABSORBANCE } & : 0.22\end{array}$

\begin{tabular}{|c|c|}
\hline $\begin{array}{c}\text { VOLUME OF } \\
\text { BACTERIOCIN } \\
\text { CONTAINING } \\
\text { PURIFIED } \\
\text { SAMPLE }(\mu \mathrm{l})\end{array}$ & $\begin{array}{c}\text { DIAMETER OF } \\
\text { ZONE OF } \\
\text { INHIBITION }(\mathrm{mm})\end{array}$ \\
\hline 50 & 9.0 \\
\hline 75 & 11.0 \\
\hline 100 & 13.0 \\
\hline
\end{tabular}

\section{DISCUSSION:}

In the present study, bacteriocin, a protein that inhibits the growth of bacteria produced by Lactobacillus bifernentans was recovered, partially purified and tested for its antibacterial effect against selected bacterial strains. The lowry's method was performed to determine the concentration of protein present in the sample and the concentration was found to be $1.5 \mathrm{mg} / \mathrm{ml}$. The Size Exclusion Column chromatography was standardized by running Blue Dextran and the void was found out. With the void volume of Blue Dextran, the flow rate required for running the sample was found out. In general, bacteriocins found in lactobacilli have been characterized as proteinaceous antagonists, displaying a narrow range of inhibitory activity towards closely related species within Lactobacillaceae (18). Results obtained by testing the crude and partially purified L.bifermentans sample against selected indicator strains suggest high antibacterial properties.The bacteriocin described in this study inhibited Staphylococcus aureus and Bacillus subtilis. Inhibitory activity was not shown against Escherichia coli. Increased activity has been observed upon purification of bacteriocin by Size Exclusion Column chromatography.

Bacteriocins have been reported to be inhibitory against several other bacteria $(17,11)$. Nisin,the best known LAB bacteriocin has been repeatedly shown to be safe and effective for use in foods over the past 30 years. $(8,13)$. Bacteriocin production was strongly dependent on $\mathrm{pH}$,nutrient sources and temperature(29).

Ever since the era of Louis Pasteur and Robert Koch, there has been scientific recognition of an essential need to control detrimental microorganisms in our environment as well as in food industry. As therapeutic antibiotics are prohibited for use in foods, the utilization of antagonistic additives with preservative or antimicrobial properties has since become a trademark approach in food safety and preservation. Bacteriocins are produced by bacteria and possess antibiotic properties, but bacteriocins are normally not termed antibiotics. Bacteriocins differ from most therapeutic antibiotics in being proteinaceous and generally possessing a narrow specificity of action against strains of the same or closely related species (Tagg and others 1976). Because LAB and their metabolites have been consumed in high quantities by countless generations of people in cultured foods with no adverse effects, the LAB continue as the preferred source for food-use bacteriocins, either in the form of purified compounds or growth extracts.

Our study revealed that Lactobacillus bifermentans showed antibacterial activity against some common pathogenic and food spoilage microorganisms by the production of bacteriocins. Lactobacillus bifermentans is especially important in fermentation industry. bifermentans means "Doubly Fermenting", therefore L.bifermentans finds an exhaustive application in the field of fermentation and food processing.

Since much information is not available on Lactobacillus bifermentans till today, further research must be done by researchers to explore its potential use as an antimicrobial agent to prevent the proliferation of other pathogens and foodspoilage microorganisms. Further research is required for better understanding of interactions between various bacteria. 


\section{REFERENCES:}

[1] Barefoot,S.F and Klaenhammer,T.R(1983). Detection and activity of lactanin B, A bacteriocin produced by Lactobacillus acidiphilus. Applied and environmental microbiology, 45, 1808-1815.

[2] Boris,S.R.Jimenez-Diaz,JL.aso and C.Barbes.2001.The partial characterization of a bacteriocin produced by a human Lactobacillus delbruckii isolate with probiotic potential.J.Applied.Microbiol.,91:328-333.PMID11473598.

[3] Christina.I.Mortvedti \& Ingolf F-NES(1990). Plasmidassociated bacteriocin production by a Lactobacizzus sake strain.Journal of General Microbiology, 136, 1601-1607.

[4] Cooper,P.C., Hawkins,F.K.L.\&James,R(1986). Incompatibility between E colicin plasmids. Journal of General Microbiology.132, 7, 1859-62.

[5] Daeschel,M, and Klaenhammer,T.R.(1985). Association of a 13.6-megadalton plasmid in Pediococcus pentosaccus with bacteriocin activity. Applied and Environmental Microbiology, 50, 15381541.

[6] Daeschel,M.A., Mckenny,M.C and Mcdonald,L.C(1986). Characterization of a bacteriocin from Lactobacillus plantarum. Abstracts of the Annual Meeting of the American Society for Microbiology. $86,277$.

[7] Deklerk,H.C and Smit,J.A(1967). Properties of a Lactobacillus fermenti bacteriocin. Journal of General Microbiology, 48,309-3 16, 1859-1862.

[8] Delves-Broughton J(1990). Nisin and it uses as a food preservative. Food Technol, 44:110-117.

[9] Dicks LMT;M.Silvester,PA Lawson,MD Collins(2000)." Lactobacillus fornicalis sp.nov.,isolated from the posterior fornix of the human vagina". International journal of systematic and evolutionary Microbiology(society for General Microbiology) 50

[10] Ferreira,C.L and Gilliland,S.E.(1988). Bacteriocin involved in premature death of Lacidophilus NCFM during growth at pH 6. Journal of dairy science 71,306315.

[11] Flythe MD,Russell JB(2004). The effect of $\mathrm{pH}$ and a bacteriocin (bovicin-HC5) on Clostridium sporogenes MDI,a bacterium that has the ability to degrade aminoacids in ensiled plant materials. FEMS Microbiol Ecol. 47:215-22.

[12] Hardy,K.G.(1975). Colicinogeny and related phenomena. Bacteriological Reviews 39,464-5, 15.

[13] Janes ME,Nannapaneni R ,Johnson MG(1999). Identification and characterization of two bacteriocin producing bacteria isolated from garlic and ginger root. J.Food Prto., 62:899-904.

[14] Joerger,M.C and Klaenhammer,T.R.(1986). Characterization and purification of helvection $\mathbf{J}$ and evidence for a chromosomally determined bacteriocin produced by L.helveticus.481. journal of Bacteriology, 167,439-446.

[15] Kale-ita,C and Ention,K.D(1989). Nisin,a peptide antibiotic: cloning and sequencing of the nis A gene and post-translational processing of its peptide product. Journal of Bacteriology, 171, 1597-1601.

[16] Karovicova,J and Z.Kohaqjdova,2005. Lactic acid fermentation of various vegetable juices. Acta Alimentaria Chem.Food Sci., 34:237-246. DOI: 10.1556/AAlim.

[17] Kleanhammer TR (1983). Genetics of bacteriocins produced by Lactic acid bacteria. FEMS Microbiological Reviews.12:39-86.

[18] Klaenhammer T.R. (1988). Bacteriocins of Lactic Acid Bacteria. Biochimie., 70-337-349.

[19] Lactobacillus-Med line plus.

[20] Ljungh,Asa; Wad strom, Torkel,eds.(2009). Lactobacillus Molecular Biology: From Genomics to Probiotics.Caister Academic Press. ISBN 978-1904455-41-7.

[21] Makarova, K;Slesarev,A;Wolf,Y;Sorokin,A;Mirkin,B;Koonin,E;Pa volov,A;Pavlova.N. et al(oct 2006). "Comparative genomics of the lactic acid bacteria". Proc Natl Acad Sci USA 103(42):15611-6 doi: 10.1073/pnas. 0607117103. PMC 1622870.PMID 17030792.

[22] Mccormick,E.L. and Savage,D.C(1983). Characterization of lactobacillus species strain 100-37 from the murine gastrointestinal tract:ecology,plasmid content and antagonistic activity toward Clostridium ramosum HI. Applied and Environmental Microbiology 46.

[23] Sahota,P.G.Pandove,S.Jairath and G.Banta,2008. A Functional probiotic beverage kanji-Indian.J.Ecol. 35:101-102.

[24] Scherwitz TZ,K.M.,Baldwin,K.A\&Mckay,L.L(1983). Plasmid linkage of a bacteriocin-like substance in Streptococcus lactis subsp.diacetyl lactis strain WM4: transferability to Streptococcus lactis.Applied and Environmental Microbiology 45, 15061512.

[25] Schillinger,U and Lucke,F.K(1989). Antibacterial activity of Lactobacillus sake isolated from meat. Applied and Environmental Microbiology 55, 19011906.

[26] Servin,A.L.(2004)Antagonistic activities of Lactobacilli and Bifidobacteria against microbial pathogens. FEMS Microbiology Reviews, Vol.No.28.pp 405-440.

[27] Tagg,J.R.,Dajani.A.S. \& Wannamaker,L.W.(1976). Bacteriocins of Gram-positive bacteria. Bacteriological Reviews 40,722-756.

[28] Tagg,J.R.,Dajani.A.S. \& Wannamaker,L.W.(1976). Bacteriocins of Gram-positive bacteria. Bacteriological Reviews 40,722-756.

[29] Todorov SD,Dicks LMT(2004). Comparison of two methods for purification of plantaricin ST31,a 
bacteriocin produced by Lactobacillus plantarum ST31. Enz.Microbiol.Technol. 36:318-326.

[30] Upreti,G.C and Hinsdill,R.D(1975). Production and mode of action of lactonin 27: bacteriocin from a homofermentative lactobacillus. Antimicrobial agents and chemotherapy 7,139-145.

[31] West,C.A and warner,P.J(1988). Plantacin,a bacteriocin produced by L.plantarum NCDO 1 193. FEMS Microbiology Letters, 49,163-165. 